\title{
The limitations of the Transnationalised State thesis in neo-Gramscian IR: the grounds for a Strategic-Relational Approach*
}

\author{
Marco Antonio de Meneses Silva1
}

\begin{abstract}
This article addresses recent critical literature in International Relations, on the transnationalisation of the state. It identifies a trend within neo-Gramscian thinking on the matter that awards excessive credence to the agential nature of hegemony with regards to the transnational state, class formation and alliances. In order to correct the imbalance implicit in the inherent instrumentalism of such accounts, a dialectical approach is suggested. This entails re-examining the Gramscian notion of the historic bloc on the one hand, and the employment of the Strategic-Relational Approach (SRA) of Jessop on the other. As a consequence, both challenge the phenomena of transnationalisation, indicating the need for alternative conceptualisations in the debates on the state, globalisation, and hegemony. The article finds that structural readings of the historic bloc, and the SRA initiatives reveal the limitations of the current literature in conventional neo-Gramscian thinking, in addition to the need for further developing readings on the state and hegemony.
\end{abstract}

Keywords: Globalisation. Transnationalisation. Hegemony. Historic bloc. Strategic-Relational Approach. State theory.

* Recebido em 18.04.2010

Aprovado em 20.05.2010

1 Bacharel em Relações Internacionais, e em Ciência Política (Universidade de Brasília), Mestre em Relações Internacionais, e aluno do programa do doutorado em Relações Internacionais (University of Kent, Reino Unido), professor do curso de Relações Internacionais do Centro Universitário de Brasília - UniCEUB.

e-mail: marcodemeneses@gmail.com 


\section{Introduction}

The core aim of this article is to explore the theoretical underpinnings of recent literature in IR that is broadly inspired by neo-Gramscian thought. The centrality of the concept of hegemony in the efforts of scholars who have looked towards Gramsci for inspiration has warranted much attention. Here, greater consideration is paid to the analytical category of the historic bloc as a means of overcoming suggested shortcomings in the literature. My wider research concerns relate to the densification and the endurance of neo-liberalism within South American political systems, particularly those in which political forces that antagonise with neo-liberalism have come to power. This facet will appear recurrently in the article as a means of providing the empirical grounding for the theoretical debates. In sum, the main objective of this article is to theoretically and conceptually ground the bases on which agential trends seemingly dominate the literature on the hegemony of neo-liberalism, by also examining analyses at the competing extremity, in the direction of more structural approaches.

By pointing towards overemphasis on agency, reference is made to hegemony as the product of the actions and interactions of a transnational capitalist class (TCC) owing to the dissemination of transnational corporations. It is claimed that such transformations provide causality for political transformations that have ensued. This is the background for the emergence of the transnationalised state thesis. On the other hand, I contend that the bias towards agency might well be balanced by engaging with analyses that award greater emphases on structures.

Here, structures are understood as the amalgam of social and material forces, the latter in relation to production. There is a relatively static nature to the material forces of production, which deems them the least variable elements in historical development. The elementality of the superstructure challenges the organic limits imposed by the action of the superstructure.

The notion of a transnationalised state arguably neglects theorising over capitalism and the state that has occurred for some time. We are left with the impression that many authors working within neo-Gramscian International Relations have attempted to further the application of concepts such as that of hegemony with little regard to previous debates on capitalism and the state. I do not intend to deny the power 
of capital as it transnationalises. I contend is that it may be far-fetched to develop an overarching thesis that pre-determines the consequences for individual states once the presence of transnational capital is established. In this, I suggest an excessive agency and the inherent instrumentalism of what we might tentatively call "mainstream neoGramscian" thought, need reconsideration. The necessity is greater with particular regard to the consequences for the state.

The focal points in this attempt to theorise neo-liberal hegemony is the Gramscian concept of historic bloc, coupled with the strategic-relational approach to the state. I wish to challenge the transnationalised state thesis which is arguably prevalent in neo-Gramscian analyses of the consequences for the state of the transnationalisation of capital. I argue that the historic bloc is the pivotal concept for the establishment of a more structural neo-Gramscian analysis of contemporary politics.

Furthermore, I shall challenge the most common interpretations of the concept as this is the likely source for the primacy of agency in the notion of the transnationalised state. By examining the formation and change in historic bloc, particularly if emphasis is placed on the structural sphere of the dialectical and organic relation with the superstructural, the concept can mediate the ensuing discussions on power, hegemony, transnationalisation and the state. On the other hand, the call for a more dialectical conceptualisation of the transnationalised state argument also occurs on the grounds of its inherent instrumentalism. The belief that state is open to capturing by dominant classes, who will subsequently employ the state apparatus to establish and increase their own interests and benefits, is confronted. I argue that a strategic-relational approach (SRA) might well help elucidate the grounds on which the continuance of neo-liberalism occurred, beyond the detection of an alliance between transnational capital and segments of the domestic dominant classes.

SRA emphasises that state apparatus and practices are materially interdependent with other institutional orders and social practices. The state is socially embedded. Political processes and state capacity are formed and transformed by divisions of society, and are strategically selective. In this sense, strategies are contingent on those that preceded them. State structures bear an impact over political forces to pursue particular interests and strategies over state capacities. The nature 
and impact of state power (capacities and liabilities) depend on historically and spatially contingent structural relations between political and civil society system - the links between the state and the broader social environment (JESSOP, 2008 ).

As transnational capital is the driving force behind both dimensions of globalisation of interest here - economic and political -, examining its impact on the elevation of the anti-neo-liberal forces into power is imperative. Thus, for some, the submission of South American states to the economic project of transnational elites, i.e. neo-liberalism, becomes more understandable as it serves the means of preserving the privileges of, essentially, transnational capital, but through an alliance with domestic class fractions, and other social groups of the elite. In other words, the submission is an expression of the influence of transnational capital over the political processes of the state.

It is noteworthy to mention that the way in which the problematique has been expressed - i.e. the endurance of neo-liberalism - awards no privilege to either agential or structural accounts. If we inspect such analyses initially, there might be an implicit notion of agency present in accounts that contend an act of submission. It presumes not only that other strategies were possible for the agent(s), at least in theory, but also that neo-liberalisation was a largely autonomous act of will. To some extent, it also discerns an element of prior reluctance, perhaps outright opposition, to neo-liberalism to have been present. Accounts that come to terms with the continuance of neo-liberalism, which explain and justify alleging that there was no other (feasible) alternative ${ }^{2}$ are commonplace.

The decision to examine the continuance of neo-liberalism from a structural standpoint shall become better served by rephrasing the problematique. Instead, my aims are to initially provide a theoretical framework from whence to shed light on the problematique. As such, I am interested in approaches that seek a more balanced stance, thus heightened structural perspectives would undermine and challenge to some degree the notion that agency holds the foreground, and per se, is at superior position to analyse the problematic. In order to argue that the

2 This is the 'there is no alternative' (TINA) claim. 
hegemony of neo-liberalism ought to be understood within a framework that relates to globalisation, more attention is crucially required to the processes whereby changes in the social relations of production and finance relate to the role and form of states. This is aligned with the call for neo-Gramscian thinking in IR to favour scrutinising the relationship between hegemony, historic blocs and the state (JOSEPH, 2009).

The crux of the paper therefore still relates to a structural approach in uncovering the mechanisms through which the strategic engagement with the hegemony of neo-liberalism took place, in which transnational capital engaged with domestic social groups, comprising an historic bloc, and materialising the conditions. This may well have established structural arrangements that increasingly augmented the ultimate political power of transnational capital within the historic bloc, with manifest consequences for the role of the states. However, this needs to be investigated. The concept of an historic bloc is highly complex and the object of interpretive dispute, thus it warrants a more detailed presentation.

The paper is structured in two parts. In the first, I construe the essence of the claim that the political agency of a transnational capitalist class behind hegemony has produced a transnationalised state. Initially, the structural changes in economic activity and its consequences and repercussions in the political domain, in addition to the role of transnational capital are the object of analysis. The structural changes that globalisation has produced are the focus of concern, as is the function transnational capital performs in the economic and more importantly the political dimensions to globalisation. This is followed by the presentation of the emergence of a transnational capitalist class argument. More than the evidence of its existence, the claim is made that the transnational capitalist class exercises outright political agency and is active in the operation of hegemony, a component of a transnational historic bloc, a theme which permeates much of the neo-Gramscian production in International Relations, and will be subjected to contention below.

From there, I examine differing versions of the implications for politics, markedly for the state. Globalisation has a political dimension that relates to how states are involved in the transformations that have characterised recent decades. 
From the debate of whether the state is a subject or object of these changes, to the dispute over the agency of the TCC, these are some of the issues that divide this set of scholarship.

The second part is dedicated to presenting the case for focusing on the historic bloc as a means of 'taking a structural turn' in Neo-Gramscian International Relations. I examine how the concept has tended to be read. I argue that if the concept is reread in a manner that places more emphasis on the structural realm, many of the problems regarding excessive agency might be overcome. What is required is a reassessment of the immoderation of the value of agency.

The second conceptual feature of the transnationalised state to be disputed is its inherent instrumentalism. By this, I refer to the understanding that states are essentially the instruments of ruling classes. The theme has been the object of debate in wider Marxist theorising on the state. (HAY, 2006) ${ }^{3}$ Transnationalised state theorists claim that alliances between a transnational capitalist class, and willing counterparts in the dominant groups within states - elected officials, senior bureaucrats, domestic bourgeoisie - have produced an effective control over key entities of the state apparatus. I contend that by examining alternative theorising on the state, such as its relative autonomy in Poulantzas, $(1975,1978)$ and further, in the strategic-relational approach of Jessop $(2002,2008)$, more structural accounts may well have a good deal to add to our analyses.

\section{The transnationalised state thesis}

The rise of a transnational capital and how states' roles and forms have been transformed are two essential structural processes of globalisation. During the latter half of the twentieth century, especially from the 1970s onwards, significant transformations were taking place in the economy, markedly in production, arguably even more so in finance. These involved a shift from a process of greater internationalisation, initially, towards the increasingly transnationalisation of economic

\footnotetext{
${ }^{3}$ It was a position Ralph Miliband gained notoriety for.
} 
relations. The transition has signified changes in the world economy, which have affected its distinct institutional, organisational, political and regulatory structures. The emergence of transnational capital is a defining feature of this phase. It is the basis for economic globalisation in the sense that the material and political obstacles to freely moving capital around the world have diminished considerably (ROBINSON, 2001, 2004a). ${ }^{4}$

It is essentially the globalisation of the production process that determines the distinction between the world economy and a global economy. The mobility of transnational capital has enabled the reorganisation of production on a global scale in order to ensure maximum profit-making, subjecting national production to a condition of fragmentation and external integration. Transnational capital, organised into Transnational Corporations (TNCs) have penetrated and now manage vast chains of global production and services across national borders. These networks become effectively global as they integrate various agents and social groups into complex global networks. Hence, domestic circuits of production and distribution can no longer be easily differentiated from the globalised ones. Other consequences include the incentive to transnationally (outwardly) direct the decisions of certain agents and social groups, in other words, to seek deeper integration into the global economy (ROBINSON, 2001).

This has led to a number of accounts that suggest transnational capital is accountable for the emergence of a new form of state - the transnational state. It must be said that I do not suggest there is a single body of neo-Gramscian IR scholars that have produced a consistent, coherent, and cohesive theory. What I will refer to is a loosely identifiable concept that has received the contribution of prominent scholars associated with the development of Gramscian ideas in IR. In essence, the transnationalised state thesis stakes the claim that the penetration of capital into other states, whether it be productive and/or financial, has enabled fundamental changes in the political domain. Transnational capital has effectively exercised political agency

\footnotetext{
4 Robinson takes this argument one step further, claiming the rise of transnational capital is of unparalleled importance and sets the scene for the rise of a new form of state, as I shall examine below.
} 
through the formation of a transnational capitalist class. This class has become increasingly powerful to the extent that it has captured crucial agencies within the framework of the state and is able to ensure its interests are catered for. Thus, from the inside, through the co-optation of members of the political and economic elite, the TCC retains a stranglehold over the control of the state in order to preserve and expand the privileges this class holds. From the outside, state form and policies are dictated by international organisations that are likewise controlled by the TCC.

More specifically, the process here at stake is that of transnational class formation. These phenomena are linked to the different stages of internationalisation of capital. By capital, reference is made not only to one of the factors of production (land and labour being examples of others). This is the position of neo-classical economics. Capital is also a social relation in the sense that it exploits labour in order to extract a surplus. These relations materialise from production (GILL \& LAW, 1994, p. 8). It is how people are involved in production processes that establish whether a class exists. Thus, production relations are necessary but insufficient for the appearance of classes. Class identity and collective agency depend on social practices and events (COX, 1987, p. 355).

The different categories of capital are also reflected in subdivisions within the capital class. As such, there might exist productive, financial and trade capital as class fractions. Such fractions are potentially in competition against one another, which is explained in terms of the different material interests and levels of consciousness, i.e. the ability to perceive and politically further their interests compared with those of other classes and groups. The establishment of transnational circuits of capital accumulation through the penetration of transnational capital (productive, financial) produces consequences in terms of the configuration of classes in any given state. Gill claims that with transnational corporations at the forefront, leading elements of this fraction linked to global circuits of accumulation have highly developed a consciousness, shared institutions, and material interests that are convergent in general, divergent in potential. This transnational capitalist class is alleged to be centred in North America, Western Europe and Japan, but with increased ramifications in the states of the periphery 
(GILL, 1990, p. 89). Schwartzman refers to these established agents as emissaries. They include representatives of the IMF, World Bank, AID, US Trade Commissions, US Secretaries and high officials of other core countries. In the new institutional pillars that facilitate global capital flows, they also include representatives of private rating agencies and investment companies (SCHWARTZMAN, 2006).

The development of a TCC perspective has relied on the instrumental function of planning groups. These can be exemplified by institutions such as the Trilateral Commission, the Club of Rome, the Council on Foreign Relations, the Bilderberg conferences. A yet more comprehensive example is that of the World Economic Forum, an annual conference attended by prominent worldwide business and political figures. They serve as class organisations constantly adapting to the effective balance of forces challenging them. They are also a meeting ground to develop common strategies and to adjust the prevailing concept of control in response to resistance (VAN DE PILJ, 1998; GILL, 1990).

However, apart from the possibilities for political agency exercised by the TCC, a closer look at the political power and the role of the state needs to occur. We have examined how changes in production, finance and trade, are said to have enabled the emergence of a transnational class that operates and engages in economic relations across national borders. These transformations in the economic dimension are believed to have produced effects in the political realm. States have found it increasingly difficult to "regulate economic activity within national borders, to capture and redistribute surpluses, to harmonize conflicting social interests and to realize their historic function of sustaining the internal unity of a nationally conceived social formation" (ROBINSON, 1995, p. 35). These can be portrayed as the economic dimensions to globalisation. Once again, for Robinson, there is a base-superstructure relation at play. Through the emergence of a qualitatively new base - a global economy - the superstructure is also being transformed as we witness changes in world politics and international relations. But what sort of transformations in the political dimension have developed? If globalisation is to be understood as the transnationalisation of economic activity in the economic realm, in the political realm, we presumably find its counterpart: the transnationalised 
state $^{5}$. By this, it is implied that as production and finance have become transnationalised, social forces linked to these have increasingly become political agents, actively engaging in the politics of states and across national boundaries. These, in turn, evolve from and become tied into broader and more complex political structures, part of transnational production and finance. The structural and superstructural elements form a diachrony, once analyses focus on the interests and activities of classes, whether transnational or not.

In other words, the point here is that the range of phenomena implied in globalisation has affected the state. References are commonly made to a diminished state, 'helpless victims of the rise of global markets' (PANITCH, 1997), in addition to a decline in national sovereignty.

The initial assumption that the state relinquishes ground in favour of capital, however, can be challenged. The transformations implicated in the transnationalisation of the state should not to be understood as state withdrawal. It may be the case that states have not only exercised agency in these processes, as they have also to some extent willingly assumed new functions. The question of whether the role of states have increased or diminished has not been adequately addressed here. There is an underlying notion of an autonomy of the state, in opposition to the downright object of the capture of dominant social groups, be them a domestic or transnational bourgeoisie. What appears to be missing is an account of how hegemony is played out, how the historic bloc is articulated once transnational capital has been introduced. This will bear consequences on the form of the state and how it behaves vis-à-vis the debate on its retreat, withdrawal or diminution. On the other hand, it has also emerged that there are no fundamental incompatibilities between transnational corporations and states.

Cox departs from the particular configuration of social forces which inevitably support a certain form of state, the limits to its purposes and the type of action. Such constraints on its actions are contingent on the way in which world order is projected upon the state. The issue at hand is not one of enlargement or

\footnotetext{
5 There is difference here to what Robinson calls a Transnational State (TNS).
} 
diminution of the state, but of transformation in its structure and role. This transformation largely involved processes of domestic adjustments and compliance to international agreements and obligations. The agents of this process were located within the state: bureaucratic fragments were involved in negotiating with the mostly external hegemonic power structure. The redefinition of the role of the state occurred from the outside in. It was an ideological effort cooperatively conceived by unofficial agencies, although subsequently endorsed by official ones ${ }^{6}$. From the domestic perspective, there was a transfer of power away from agencies aligned with domestic social forces and towards those associated with the transnational process of consensus formation. Internationalisation of the state here implies the structural impact on national governments of this centralisation over policy. The central characteristic of the state as a transmission belt becomes one of conforming national economic practices and policies to the apparent demands of the global economy. This takes place through the pre-eminence awarded to prime ministerial and presidential offices, foreign offices, treasuries, and central banks in order for them to become instruments of policies conveyed from the agencies of the global economy (COX, 1997).

Here we also find a series of problems. Once more, the inherent instrumentalism is quite evident. Structure is reduced to the repercussions within the state apparatus of the newfound power exercised by transnational capital, in terms of its adjustments to cater for the interests of the latter. As its framework has been modified, the state has been captured from the outside-in, the object or instrument of the seizure of the hegemonic power structure. Although Cox has appropriately identified the changes in production as the material base for the emergence of the transformations in state forms, his emphasis on this capture from the perspective of the agents within state bureaucracies reduces his argument considerably, restricting it to an excessively agential nature. Where do the powers and possibilities of such agents emerge from? Once again, the need for a structural grounding becomes apparent.

${ }^{6}$ In the case of the former, the Trilateral Commission the Bilderberg conferences and the Club of Rome are examples; in the case of the latter, the OECD. 
The next perspective picks up on the role of mediation, but significantly furthers its argument. It is also arguably the clearest example of over-emphasing agency that I am attempting to critique. This is Robinson's transnational state (TNS) concept. He has taken the transnationalised state thesis and pushed it further. However, there are similarities with the afore-mentioned accounts. Globalisation is understood to reconfigure world social forces in a very dramatic way. It becomes structurally impossible for individual nations to sustain independent, or even autonomous, economies, political systems, and social structures. As such, the state is not "withering away" but supposedly being transformed in its functions, from where it develops to become part of a larger TNS. This has occurred through shifting the function from the formulation of national policies to the management of policies originated from supranational institutions. Whereas prior to the mechanisms globalisation has instilled the state was able to mediate the relation of subordinate classes to capital, this function has been modified with the occurrence of a process of transnational class formation. Transnational capital has acquired the unique ability of projecting its power over nation-states and popular classes, an expression of which is the state's increasing inability to intervene in economic policies and practices. This has manifested as an institutional contradiction. On the one hand we find the structural power of transnational capital, which is supposedly able to instil discipline or destabilise policies that are enacted in the eventuality of the states being captured by popular classes or national fractions of domestic dominant groups. On the other, there is still the direct power of states. This institutional contradiction will be resolved by means of the capturing of local states by agents of global capitalism, as local state practices are increasingly harmonised with global capitalism. The TNS emerges through the agency of the TCC that establishes a network of supranational institutions and relationships that bypass formal states, whilst exploiting national governments. National states are simultaneously transmission belts and filtering devices, but also active instruments for the further development of the global capitalism agenda. In closer detail, in this account what is at play is less that states are diminishing, becoming powerless, or irrelevant. It is more about how the restructuring of the state has enabled the interests of transnational capital and global institutions to be catered for, in detriment of social groups and classes associated to national accumulation. The struggle between declining national fractions of dominant groups and rising transnational fractions has tended to represent the backdrop to political and ideological debates. The aim of 
either parties would be to ensure that state intervention furthers their own interests, which in turn requires its capture (ROBINSON, 2004a).

By way of a partial conclusion, I would like to restate my argument. Rather than pursuing the path of agency as the overriding perspective, I claim that a more structural based approach may have a lot more explanatory power to offer. I am convinced that the neo-Gramscian approaches I wish to draw from in my research have largely given far too much prominence to agency by their focus on the formation of a transnational class alliance as the key to understanding hegemony. I have drawn from the concept of Globalisation, with a focus on how the transnationalisation of economic activity has produced consequences not only of an economic, but also of a political nature. For agential accounts, the economic consequences have to include the rise of a transnational capitalist class through the spread of transnational corporations. The political consequences have incorporated the debate on the consequences at the political level, with some arguing the rise of a transnationalised state.

It is highly controversial to suggest that a transnational political elite has consciously assembled a tentative political framework in which the centre of power is occupied by supranational institutions under its control. Moreover, that states have become little more than appendices, instrumental in the furtherance of the agenda of global capitalism is perhaps either an overstatement of the power of transnational capital, or an under-theorisation of the power of states. Once again, can states be equated to objects for the capture and subsequent dominance of the transnational elite?

The notion of a transnationalised state arguably neglects theorising over capitalism and the state that has occurred for some time. We are left with the impression that many authors working within neo-Gramscian International Relations have attempted to further the application of concepts such as that of hegemony with little regard to previous debates on capitalism and the state. I do not intend to deny the power of capital as it transnationalises. What I contend is that it may be far-fetched to develop an overarching thesis that pre-determines the consequences for individual states once the presence of transnational capital is established. In 
this, I suggest an excessive agency and the inherent instrumentalism of what we might tentatively call "mainstream neo-Gramscian" thought with particular regard to the consequences for the state need reconsideration.

The state has been seen as the proactive agent of transnationalisation in some accounts, whilst the passive object of the capture of the TCC in others. These perspectives do not seem contradictory in the least. However, the proactivity or passivity in the face of the power of transnational capital is a dialectic that permeates both debates: of whether the state is a transmission belt or an active agent of globalisation, and that of the structural power of capital against the direct power of states. Notwithstanding, both debates require an analysis of how the national historical bloc ${ }^{7}$ is articulated within a historical context. The extent to which the state has been transformed and has acquiesced to the interests of a transnationalising coalition, one that fuses transnational and domestic elements, and that is represented by the TCC at its core, maybe a misguided endeavour. This analysis will attempt to reveal that to make sense of political decision at a precise moment requires a closer look at how power is organised within the political domain. It makes little sense to seek an a priori answer to solving this methodological dilemma at the expense of examining specific state contexts.

An angle that justifies examining this context is the contradiction between the structural power of transnational capital and the direct power of state. The thesis presented argued that if it is the case that the social groups and classes tied to domestic accumulation have attained little if any success in the power struggle against a coalition of domestic and external transnational forces, than the proposition of the emergence of a TNS gains explanatory powers. This function cannot be decoupled from that of reinforcing the power structures the TCC has attempted to construct, within the state, and at the supra-national level: the TNS. If, on the other hand, the same groups have managed to counter this transnationalisation impetus, then states might act differently to being agents for the development of the agenda of transnational capital.

\footnotetext{
7 Configuration of the power relations of domestic classes and social groups.
} 


\section{Overcoming the Transnationalised State}

The application of the Gramscian notion of hegemony to the international realm has tended to award greater relevance to an ideological, superstructural element (COX, 1997; VAN DE PILJ, 1998; ROBINSON, 1996). More precisely, it has been commonly understood as an incitement to examine transnational, cross-border alliances between economic and political elites. I claim this paints an incomplete picture. In this section, I begin by reverting back to the concept of historic bloc, particularly emphasising how this category originally attempted to reconcile changes at the level of production, of the structures, and those superstructures, I suggest the limitations of "surface hegemony" might be overcome.

The inherent instrumentalism I have identified also needs to be challenged by a perspective of the state that takes into account its strategic-relational nature, one that allows us to incorporate the underlying social structures as a means of understanding the articulation and interaction of social groups. What is needed is a more comprehensive engagement with the conceptualisation of the state, in particular one that moves beyond a narrow, instrumentalist understanding towards an approach that emphasises its relative autonomy. The intensity and exact nature of the transformations in the state demands that the pre-eminence of the political project of social groups or classes aligned with global, as opposed to those of national accumulation, be scrutinised. I shall suggest that the ideas of authors linked with a more structuralist approach to conceptualising the state may have a good deal of substance to bring to the debate.

\section{From historic bloc to power bloc}

Initially here, my primary aim is to present the conceptual discussions surrounding Gramsci's notion of an historic bloc. I have accepted the challenge directed towards over-emphasis on agency. Joseph finds "[...] such claims rather problematic and suggest [here] that a more fruitful approach is to shift focus on the formation and change in historic blocs" (JOSEPH, 2009). The call to arms can only succeed if such approaches reconsider the predominant understandings of the historic bloc. I believe this to be central in our understanding of power, hegemony, the 
state and transnationalisation. It bears a fundamental impact, therefore, on how greater relevance to structures can be awarded in our analyses. I suggest that the preceding accounts of transnationalisation and the state lack a more substantial engagement with the notion of the historic bloc. It can provide us with a form of linking the superstructural and the structural, as Gramsci originally intended, and from there to the necessary connection with the state.

I shall begin by presenting a broad definition of the term, and then subsequently examining how different readers have interpreted the notion, with particular concern devoted to how the concept might be employed in the attempt to structurally ground our understanding of power. Once again, the emphasis shall be on foregoing the excessive weight agency has built in favour of pending the balance towards structure, by converging on the organic requirement and the dialectical relation inherent to the historic bloc. I intend to reveal that, through neglecting how the concept demands greater emphasis on material conditions, it is little wonder that attempts at understanding the transnationalisation of the state covered (and correlated themes) appear overly devoted to agency. From there, I shall return to the transnationalisation and the state debate attempting to incorporate the historic bloc. Hence, a succinct definition of the term is the starting point.

It is through the historic bloc that Gramsci attempts to thread the political (intersubjective) and the economic (material) together, by combining the superstructural and structural realms. The relation between the two complex spheres is dialectical and organic. The historic bloc is closely connected to the hegemony in the sense that it is through the interaction between both realms that the former operates. There follows a more thorough examination of the elements that comprise the historic bloc.

As seen, the premises on which the historic bloc ought to be understood require a dialectical and organic relation between structure and superstructure. With the concept of historic bloc, Gramsci attempted to reconcile ideas, politics and economics, which were convertible into one another (apud COX; SINCLAIR, 1995, p. 118). Expressed as a formula, and in its crudest characterisation, it is formed by structure and superstructure. In other words, "the complex, contradictory and discordant ensemble of the superstructures is the reflection of the ensemble of the 
social relations of production" (apud COX; SINCLAIR, 1995, p. 366). There is also an element of spatial and temporal specificity present: an historic bloc is a certain historical situation.

Let us focus on the dialectical nature of the historic bloc. It is a dialectical concept in the sense that its interacting elements create a larger unity (COX; SINCLAIR, 1995, p. 131). Gramsci does not analyse the relation within the historic bloc between two elements of unequal importance. The ethico-political superstructure has an importance that is equal to that of the economic base. Structure is defined as the set of social forces and as production. This is its first aspect. The second essential aspect of structure is its relatively static nature. The set of material forces of production is the least variable element in historical development. To suggest the superstructure is primordial would be to underestimate the organic limits imposed by the action of the superstructure. The relation between the two realms of the historic bloc is dialectical, as both are equally determinative: the structural realm engenders the superstructure, which is initially a reflection. The superstructure in any given period can only develop and act within precise structural limits, thus, structure constantly influences superstructural activity (PORTELLI, 1977, p. 67).

For Portelli, the primacy of one or the other element of the historic bloc is a false dilemma. If the articulation of the bloc is taken into account, it becomes evident that its socio-economic structure is its decisive element. It is no less evident, however, that it is in the activities of the superstructure that the contradictions that emerge from the base are potentially translated and solved. The relation between both elements is organic and dialectical. Gramsci warned of the dangers of separating the two - base and superstructure -; the concept of historic bloc aims to avoid this mistake (PORTELLI, 1977, p. 67).

Although the alert to what goes on at the structural level is welcome, Portelli does not seem to have taken heed himself. Buci-Glucksmann challenges Portelli. "In this perspective, there is evidently only one historic bloc, embracing the whole of society, including the subaltern classes. The end result is necessarily that the question of intellectuals is given precedence over that of the state, for example" (BUCI-GLUCKSMANN, 1980, p. 276). The problem in Portelli, therefore, is one of 
the decoupling of the two spheres. He seems to salute the structural, recognising the distinction, but refrains from presenting an account that demonstrates how what goes on at the superstructural level reflects the base. Whilst resounding the duality on the one hand, the dialectical relation is left hovering, as opposed to grounded by substantially engaging the two realms. Portelli has fallen into a superstructural trap. He claims that the notion of a historic bloc supersedes the structural-superstructural dilemma, concurs that the relation between the spheres is dialectical, agrees once again with Gramsci that the former is reflected in the latter, however, more importantly, does not suggest how the two interact if not through the action of intellectuals. The end result is an argument that considerably favours the superstructural, one that is echoed in several of the accounts on the transnationalisation of the state, as the correlate concept of hegemony is applied in IR.

Notwithstanding, Portelli does remind us that the essential aspect of the notion of historic bloc does not reside in the distinction between structure and superstructure, but in the organic nature of their interaction: only those superstructures that are historically necessary for the base should be considered, those that give rise to a homogeneous base, that organise it (PORTELLI, 1977; BUCIGLUCKSMANN, 1980). ${ }^{8}$

Let us now turn our attention to this second requirement of the relation between structure and superstructure: the organic link. As we have seen, to form

\footnotetext{
8 This may be of consequence to his understanding of the historic bloc as a class alliance. Portelli interprets along these lines and further, that it is a class alliance in which one of the classes performs the role of producing cohesion for the others, considering the structural level. The leading class establishes itself in a twofold preeminence: at the base level, as it is the fundamental class in the economic domain; and at the superstructural level, as it exerts the ideological guidance through the intellectual bloc..However, the reduction to the notion of a class alliance is controversial, as other readers suggest this is a misapprehension. For Buci-Glucksmann, again, quoting Gramsci "the existence of an historic bloc implies an organic adhesion between intellectuals and people, leaders and led, governors and governed." (Notebook 4, 33, apud BUCI-GLUCKSMAN, p 276-9) Under these circumstances, the concept of the historic bloc extrapolates that of class alliance, as it requires a complex development of the superstructures, an integral state rooted in an organic relationship between leaders and masses. The rejection of the reduction to a class alliance is part of the present critique.
} 
an historic bloc, it is necessary for the structure and superstructure to be organically linked. This link corresponds to a somewhat concrete social organization, and emerges initially through the influence that the structure exerts on the development of the superstructure. The concept for Gill would refer to "a historical congruence between material forces, institutions and ideologies, or broadly, an alliance of different class forces. Thus, a historic bloc was the 'organic' link between 'political' and 'civil' society, a fusion of material, institutional, intersubjective, theoretical and ideological capacities" (GILL; LAW, 1994). Once again, for Portelli, any organic superstructural movement has two aspects: it must be necessary for the structure, as it is required to organise social groups, and lead them according to socio-economic conditions. As such, organic superstructural movements acquire a permanent nature. They represent ideology, the politics of diverse social groups. If they respond to such organic conditions, they will reflect structure, and comprise an historic bloc. Portelli goes on to ground the organicity of the link in the social group responsible for managing the superstructure of the historic bloc - the intellectuals (PORTELLI, 1977).

Buci-Glucksmann ${ }^{9}$ proposes a different and a more inviting route. She suggests that the key to understanding the historic bloc and its place in Grasmci's thought is to relate it to the state. This is because the organic unity of structure and superstructure in an historic bloc is not just any unity whatsoever. "As soon as the mechanisms and conditions of this unity are produced, then we move from a merely index concept to a concept that can serve as an instrument of knowledge. Gramsci's answers to this question leave no room for doubt" (BUCIGLUCKSMANN, 1980, p. 279). Because the state is a mode of class formation and organisation, which may be democratic or bureaucratic, corporatist or 'integral', the unification into a historic bloc of different social strata around a leading class takes place by way of the state (BUCI-GLUCKSMANN, 1980, p. 279). Joseph similarly advises the key would be not to define the historic bloc merely on the basis of the relations between groups, but to include the relations between groups and structures. "The historical bloc should not therefore be reduced to the question of the relation between social groups, but should be seen as the

\footnotetext{
9 She denotes the influence of the work of Poulantzas, as shall become evident below.
} 
relation between these groups and the underlying social conditions" (JOSEPH, 2009 , p. 35). The pivotal issue here is that of organisation. It intersects with the question of hegemony and that of the state. For hegemony to occur there needs to be organisation of social relations and social groups, in accordance with one another. Hegemony is related not only to the construction of a political project that tries to create the consent of social groups, but also the reproduction of the social structures that generate the material conditions for a social group to be dominant in the first place (JOSEPH, 2009, p. 36) The wider aim is to achieve the unity and cohesion of the social system in which the relations will determine what is or isn't a possible course of action (JOSEPH, 2002, p. 128). These are the foundations for the structural or deep type of hegemony in Joseph's categorisation. He wishes to distinguish this type from an agential, surface one in which conscious attempts at preserving or transforming the social relations take place, captured by the term 'hegemonic project'. The latter is the most commonplace understanding and use of the term hegemony by IR readers of Gramsci, and is particularly evident in the discussions on the transnationalisation of the state, as I have attempted to illustrate above. The former understanding is the likely link that awards substance to the organicity of the connection between structure and superstructure in the conceptualisation of the historic bloc.

Hegemony tends to build an historic bloc, to carry through a set of distinct social and political forces, and tends to conserve them through a conception of the world that it elaborated and disseminated. Base and superstructure form an historic bloc. The struggle for hegemony must involve all levels of society: the economic base, the political superstructure, and the ideological superstructure (GRUPPI, 1978).

The role of the state is crucial for the organisation of hegemony. Joseph takes a distinct position when he claims that hegemony is organised through the state. In opposition to the instrumentalism thesis, whereby the state is a mere tool of the ruling class, the argument is a functionalist one. By this, the logic is the inverse: it is the state that organises the ruling class. We are left with the vision of the state as a framework for the attempts of different social groups to realise their own hegemonic projects (JOSEPH, 2002, p. 32-33). 
Reframing the historic bloc will emerge as of crucial importance once we turn our attentions back to the transnationalised state thesis. Before that, let us examine what is meant by a transnational historic bloc. The term addresses not only issues of scale - local, regional, national, continental, global - but also issues of place -the "more or less bounded site of face-to-face relationships and/or other direct interactions among social forces" (JESSOP, 2008, p. 104). I shall converge on the former as it is an additional element that will support my critique of the transnationalised state thesis.

We are reminded by several readers of the significance spatiality receives from Gramsci, in particular in the development of the concept of an historic bloc. One of these was Portelli. An historic bloc is a certain historical situation - spatialtemporal specific. It might be located at the national level, or as Gramsci did, at the European level. Concretely, the study of the role of the fundamental class and of its historical role at the international level will enable an improved understanding of its strategy at the national level (PORTELLI, 1977, p. 90) ${ }^{10}$. Jessop interprets Gramsci as having been highly sensitive to issues of scale and its hierarchies of economic, political, intellectual, and moral power, in addition to their territorial and non-territorial manifestations. He did not take the national scale for granted, but by and large explored any given scale in terms of its interrelation with other scales (JESSOP, 2008, p. 105).

The mention of a transnational/international historic bloc has become widespread within neo-Gramscian analyses in IR. But what is meant by the emergence of a transnational historic bloc? The predominant understanding attempts to demonstrate that it is possible to conceive of new forms of state, hegemony and the formation of historic blocs on a world scale (COX, 1987; 1995). Once again, the dialectical relation between structure, now effectively transformed by transnationalisation of production, and superstructure is under scrutiny. However, in the extension of the concept of hegemony to the international domain, primacy has been

${ }^{10}$ The Risorgimento is historically situated principally at the national level. However, Gramsci does appeal to the notion of a European historic bloc to capture the premises, and understand the national strategy as a response to a regional bloc. 
awarded to the institutions responsible for the incorporation of hegemony such as international organizations, agencies within states. This superstructural struggle aims to co-opt elites and absorb counter-hegemonic ideas. The manner in which the dialectical spheres become interrelated is predominantly agential, or in Joseph's typification, surface hegemony.

The excessive emphasis on agency vein critiqued above has become apparent here also. With the "domestic" historic bloc, focus was placed on intellectuals, or on class alliances as the means of producing the synthesis between structures and superstructures. With the transnational historic bloc, the argument propounds that the structural changes brought about by globalisation, more specifically, the transnationalisation of economic activity, we have witnessed the birth of a transnational capitalist class. This class has established a coalition with elements within state and society in order to spread and deepen its hegemonic project. This line of argumentation is well represented by the work of Robinson, as we have seen. The new global ruling bloc is constituted by various economic and political forces led by the TCC. Their policies are conditioned by a developing global structure of accumulation and production, one that unites owners and manages of transnational corporations, other capitalists, elites and bureaucratic staff of supranational agencies, major figures in dominant political parties, media conglomerates, technocratic elites and state managers, in addition to select organic intellectuals. Robinson's hegemony is a function of his notion of historic bloc, not too distant to that of Portelli, along with the shortcomings we have already identified therein (ROBINSON, 2004a, p. 75-76).

Gill and Law's position is agreeable, albeit partially (GILL; LAW, 1994, p. 94-97). They are wary of the fact that the concept of an international historic bloc means much more than an alliance of capitalist interests across national boundaries. It also implies that "elements of more than one class were involved, its basis was more organic and rooted in material and normative structures of society (GILL; LAW, 1994, p. 97). Despite conceding the need for structural grounding, his notion of historic bloc reflects the turn towards the superlative significance of class interests and ideologies, as for Gill, (1990, p. 48-49): 
This means a political constellation which reflects an international congruence of objective and subjective forces. At the overt, political level, this would be manifested in an international coalition of interests. As should be evident from our earlier attempts at definition, such a bloc differs from a 'transnational class alliance' (or an 'ultra-imperialism of core capital'). This is because elements of more than one class are involved, under the leadership of a forward-looking and internationally oriented class fraction. Because of its trans-class nature, such a bloc is more organic and rooted in the social structure. It is also embedded in the modes of thought (ways of seeing and understanding the social world) of key individuals in government, and of groups and institutions in various civil societies in strong as well as less powerful nations (for example, the media and trade unions). This means that the alliance of social forces it comprises is seen, to a large extent, as 'natural' and legitimate by most of its members.

Gill also identifies an emerging transnational capitalist class fraction, mobilised by the development of its consciousness and solidarity. He, too, sees hegemony at work in international organisations, international financial institutions, private international relations councils, and 'philanthropic' institutions, such as the Ford Foundation, who sponsor conferences and fund research programmes. Through a number of alliances based on shared interests and hegemonic concepts about the way in which the world does and ought to work, a transnational class fraction has arisen at the centre of an emerging transnational historic bloc (GILL, 1990, p. 49).

Contend that the misconception in the understanding of an historic bloc continues. That the structural economic sphere has been transformed to some extent by the phenomena of the transnationalisation of economic activity is unworthy of dispute. As transnational capital penetrates, it embodies one or more social groups that will inevitably attempt to become dominant, the ruling class, within the forces of production. To proceed towards the capture of an instrumental state through the co-optation of domestic forces and elites falters by concentrating solely at inter-personal relations. This is at odds with what I believe historic bloc to mean. Hence, the argument suffers not only from the lack of organicity, but from excessive agency, as well as from perhaps misconstrued statehood. What I 
claim is needed is an examination of the historic bloc grounded on material conditions that will facilitate our comprehension of the changes in both interrelated spheres, brought about not only by the impact transnational capital has born on individual states, but how other social groups have acted and reacted. Following Joseph (2009), this is likewise tied to changes in the market and to the repercussions in terms of political power in the international system. This endeavour cannot afford to forego considerations on spatiality. There is a territoriality inherent to production, even if transnational capital controls this and other forms of economic activity. To suggest that there is a transnational historic bloc surrounding an active and ruling transnational capitalist class, one that does not seem to be spatially grounded, is highly problematic.

\section{The state's relative autonomy and its strategic-relational nature}

Once the excessive agency of the transnationalised state thesis has been countered to some extent by reviewing the concept of the historical bloc, let us now turn our attention to the second major flaw in the thesis: its inherent instrumentalism. The transnationalised state argument presented essentially defends that a transnational capitalist class, at the helm of a transnational historic bloc, has established alliances with political and economic elites across states that has enabled it to become hegemonic. By co-opting elected officials and senior bureaucrats, states have become transnationalised and are effectively under the hegemonic control of the transnational capital.

It is not to say there have been no challenges to the argument. For instance, Panitch (1997) remains unconvinced whether the important shifts within the hierarchy of state apparatuses signify a de facto rise of agents representing international capital, or whether a broader process is at work, one that aims to facilitate capital accumulation in general.This means to question what precisely transmits and links policy from state to state. Is it the case that an increasingly centralised supranational management structure is at play, one that materializes through the practice of policy harmonisation? Or is there an inability to forge policy consensus at an interstate level. How does the system of international finance internationalise the state, holding 
policy makers accountable, irrespective of ideological orientation? (PANITCH, 1997). Panitch believes the role of the state may well be one of not only internalising, but also mediating obedience to the international capitalist competition within its own domain, even if this is achieved by regulating the domestic realm.

In considering the claim that state policies weaken domestic capital, we are challenged in our understanding of the role of the capitalist state. This is where we can engage with the ideas of Poulantzas and his notion that what is of concern is the measuring of state autonomy towards transnational corporations (and towards other social forces in general). This is grounded by observing, for instance, that industrial policies were progressively more concerned with promoting the concentration and international enlargement of the states' own national capital (POULANTZAS apud PANITCH, 1997) by associating it to the international reproduction of US capital. Transnational capital's concentration of power was not in detriment of the state. Rather, the state was taking responsibility for the interests of the dominant capital.

This transnationalisation deeply affects the politics and institutional forms of these states. It inserts them in a system of interconnections which is by no means confined to the interaction of external and reciprocal pressures between states and capitals. States themselves assume responsibility for the interest of the dominant capital in its development within the domestic social formation, in its complex relation of internationalisation to the domestic bourgeoisie that it dominates (POULANTZAS apud PANITCH, 1997). The essence of the Poulantzas' theory of the state upholds that the state may be independent of the particular interests of enterprises and yet act as an ideal agent for the collective interest of capital. To ground this position, Poulantzas experiences different phases in the development of his work. Initially, he posits great emphasis on radical structuralism, only to later attribute greater preponderance to class struggle (apud HAY, 2006, p. 71-72). In Poulantzas, a structuralist account, as the term would imply, is structure- or state-centred. Simply put, it expresses a view of the relationship between the state apparatus and the ruling class - the former acts in the long-term collective interest of the latter. 
The state for Poulantzas is essential for the reproduction of capitalism as it is a factor of cohesion in the struggle for power between classes and class fractions. It emerges as the bearer of a relative autonomy, and has specific structure form and function. Whereas in the instrumentalist account power is held by the personnel of the state, hence the emphasis on alliances and co-optation, here power lies in the state apparatus. The state is viewed as a structural system with form and function determined largely independently of the aspirations, motivations and intentions of political actors or members of the dominant class. The task of reassuring the reproduction of capitalism cannot be taken on by capital: it can only be accomplished by the state that acts against the objectives of individual firms. In order to preserve capitalism, the state needs to be independent of the influence of capitalists - this is the theory of the relative autonomy of the state in Poulantzas (1973).

The state is entrusted with unifying the interests of individual capitalists in the preservation of the system, by building a power bloc that amasses the different fractions of the dominant class around an ideology that legitimises their dominance. The concept distances itself from that of an historic bloc as in the latter, subaltern classes may well be present (POULANTZAS, 1973, p. 234). ${ }^{11}$ Within the context of a dominant ideology, the power bloc is the political expression of different fractions of the dominant class. Through it, these different fractions are united to govern; in fact, their function is to translate the dominant ideology into concrete action - which expresses itself through a number of material practices, habits and values that act as cement in the link between social, political and economic relations. The dominant ideology embodies the apparatus of the State, which elaborate, inculcate and reproduce this ideology. This role is of fundamental importance for the reproduction of the social division of labour, of social classes, and of the domination of society by a certain class.

Jessop incorporates this relative autonomy in his strategic-relational approach to the state. It emphasises that state apparatus and practices are

\footnotetext{
${ }^{11}$ Defined in Poulantzas as "the particular contradictory unity of the politically dominant classes or fractions of classes as related to a particular form of the capitalist state"
} 
materially interdependent with other institutional orders and social practices. The state is socially embedded. Political processes and state capacity are formed and transformed by divisions of society, and are strategically selective. The state has distinctive resources and powers, as also liabilities and vulnerabilities. State structures have impact over political forces to pursue particular interests and strategies over state capacities. The nature and impact of state power (capacities and liabilities) depend on structural relations between the state and the political system - the links between the state and the broader social environment (JESSOP, 2008). Hence, the state is conceived of as a strategic site traversed by class struggles and as a 'specific institutional ensemble with multiple boundaries, no institutional fixity and no pre-given formal or substantive unity' (JESSOP, 2002, p. 267). The state is a dynamic and constantly unfolding system.

The core of the contribution of the strategic relational approach to state that I wish to employ in my analysis of the (post)neo-liberalisation relates to its notion that the specific form of the state in a certain national setting and at a particular moment in time embodies a 'crystallization of past strategies'. These award privileges to certain strategies and actors over others. The state, and the institutions which comprise it, are strategically selective. The structures and modus operandi of the state 'are more open to some types of political strategy than others' (JESSOP, 2002, p. 260). The dialectical relation becomes one between structures and strategies. The state presents an uneven playing field whose complex contours favour certain strategies (and hence certain actors) over others (HAY, 2006, p. 75).

The application of the strategic-relational approach invites us to conceptualise state development as a chain of political and economic crises. There can be no assured prediction as to the outcome. Not even that the state will act in the general interest of capital can be assured. The strategic-relational approach does not ensure either of the continued reproduction of the capitalist system or of its imminent demise. It is reasonable to assume unlikelihood of the latter, in the present context. In sum, it takes for granted the contingency and indeterminacy of social and political change.

How can the SRA contribute with regards to the problematic at hand, i.e. the attempts at superceding neo-liberalism? The strategic-relational approach to the 
state would invite us to examine the contingency of the struggles between classes and other forces, and the nature of the crisis itself. This is the strategically selective context within which strategies are mobilised. I have indicated that the transnationalised state thesis falls short of a more convincing account for the continuance. Rather than producing an overarching, almost simplistic account of the capture of the state apparatus through class alliances, the SRA is consistent with my contention that a lot more attention be focused on the historic bloc - most likely the power bloc - that upheld neo-liberalism's prolongation. The transnationalisation of capital has changed the strategic context in which states function and operate. However, states have maintained their core significance in capitalist accumulation (JESSOP, 2002).

Hence, the transnationalisation of the state cannot be mechanistically reduced to the contradictions that arise from the struggle between the transnationalisation of production and an outdated form of state. The core claim of the transnationalised state thesis needs to be disputed. Similarly, it is unwise to consider the state an instrument of the dominant classes, subjected to manipulation at will. This downplays the sense that internationalisation would face an opposite force, in favour of super-nationalisation, suggesting a scenario in which there is a tug-ofwar for the instrumental control of the state. Connected to this idea, we encounter what might well be at the heart of the transnationalised state debate: it suffers from the lack of a more consistent theorisation of the state prior to transnationalisation.

The point here appears to be that the role of each state remains ultimately shaped by the struggles of social forces contained within it (PANITCH, 1997). This is a far more encouraging outlook from which to examine the state, its role in (transnational) capitalist accumulation. In terms of the consequences for domestic order, different perspectives are possible. For instance, as the transnationalisation of production and finance advances, new social forces and a reconfiguration of pre-existing forces in the social order emerge. National social forces of capital and labour from national production sectors are positioned against transnational capital and labour, organized on a transnational scale. Within the former there is a further division between the subgroups who produce for a national market and 
those whose production is aimed at the international market. This seems to be an interesting point of departure from which to analyse what has happened in states with attempts at establishing a post-neoliberal era in addition to being a far more convincing angle from which to examine the impacts transnational capital projects over states.

\section{Conclusion}

The rise of a transnational capital and the consequences for states are two essential structural processes of globalisation. However, to what extent we can speak of a transnationalised state is open to questioning as the argumentation developed within neo-Gramscian IR is far too dependent on agency. I challenge the claim that transnational class formation and its consolidation through the establishment of alliances within dominant classes within and across states, a process Gill refers to as the development of globalised elites (2003), on the grounds of insufficiency. More attention needs to be paid to structural transformation to endorse. In other words, it may well be the case that the power Robinson and others claim to have identified in transnational capital is present. However, by refusing to examine the structural nature of the development of the historic bloc and by insisting on a conception of the state that reinforces instrumentality, their accounts end up developing a far more agential type of account, a surface hegemony in Joseph's typification. Transnationalised states indicate that states have deepened their ties to the global economy through transnationalisation. This notion does not concur with Robinson's thesis of a Transnational State (TNS), nor does it agree with perceptions of the transnationalisation of the state that are not sufficiently attentive to the nature of the changes wrought upon domestic historic blocs. It seems farfetched to suggest such overbearing powers are held by transnational capital in the lack of an understanding of the material foundation to such capacities, nor how it engages with other classes, dominant or subaltern. By returning to the concept of historic bloc, and interpreting along more structural lines, a more promising perspective from which to apprehend the continuance or the overcoming of neo-liberalism ought to present itself. 
In this sense, the contribution of those who have followed a more structuralist line is more than welcome. The relative autonomy that this second perspective identifies in the role of the state must be interpreted in the context of the specificities of its functions in the organisation, sanctioning and legitimisation of class domination in capitalism. Once again, this entails examining how the historic bloc is affected by the structural changes that ensue from the advent of transnationalisation, in its support of hegemony.

As I have presented, to suggest that transnational capital has emerged as a class, forging alliances with domestic classes, elected state officials and high-ranking bureaucrats strikes me as problematic on two counts. On the one hand, there is the question of the inherent instrumentalism. Here, the neo-Gramscian literature in IR is very likely at fault for not engaging at length with broader Marxist thought on capitalism and the state, such as in the instrumentalism-structuralism debate. The instrumentalist account tends to view the state as an instrument subjected to manipulation and steering in the interests of the dominant class or ruling 'elite'. The transnationalised state thesis appears to have done little more than suggest that transnational capital has become the dominant class at the helm of the state, replacing any domestic counterpart.

On the other hand, for the transnationalised state proposition, there is a dependency on agency as the focus is on inter-personal ties between members of the economic and political elites, whether they emerge domestically or 'transnationally'. As a result, analyses tend to examine agents and their intentions as causal priorities. Less attention is directed at structures and what they might add. Hegemony in the international realm becomes an issue of whether dominant classes can project their power irrespective of the boundaries by capturing the control of states, through their alliances with domestic economic and political elites, with the aid of intergovernmental organisations and private institutions.

This was a crucial part of my defence. In order to overcome the oversights of inherent instrumentalism and excessive agency, I contended a two tier approach that required re-examining our understanding of the notion of a historic bloc, and re-addressing the theorisation of the state as a complex dialectic of structures and 
strategies. This shall entail exploring the consequences for the state of how domestic capital (and other classes) might be interacting with its transnational counterpart, in a collision of strategies.

\section{As limitações à tese do Estado transnacionalizado nas Relações Internacionais Neo-Gramscianas: os fundamentos para uma Abordagem Estratégico-Relacional (SRA)}

\section{Resumo}

Este artigo trata da recente literatura crítica em Relações Internacionais no tocante à transnacionalização do Estado. Identifica-se uma tendência no pensamento neo-gramsciana sobre a matéria que concede crédito excessivo à natureza agencial da hegemonia no que diz respeito ao estado transnacional, formação de classes e das alianças. A fim de corrigir o desequilíbrio implícito no instrumentalismo inerentes a esses relatos, sugere-se uma abordagem dialética. Isso implica o reexame do conceito gramsciano de bloco histórico, por um lado, o emprego da abordagem estratégico-relacional (SRA) do Jessop, por outro. Em conseqüência, ambos desafiam os fenômenos da transnacionalização, indicando a necessidade de conceitualizações alternativas nos debates acerca do Estado, da globalização, e da hegemonia. O artigo conclui que as leituras estruturais do bloco histórico, e das iniciativas SRA revelam os limites da literatura atual do pensamento neo-gramsciana convencional, além da necessidade de novas leituras sobre o desenvolvimento do Estado e da hegemonia.

Palavras-chave: Globalização. Transnacionalização. Hegemonia. Bloco histórico. Abordagem estratégico-relacional. Teoria do Estado.

\section{Referências}

BUCI-GLUCKSMANN, Christine. Gramsci and the state. [S.1.]: Lawrence and Wishart, 1980. 
COUTINHO, Carlos N. Gramsci: um estudo sobre seu pensamento político. 2. ed. Rio de Janeiro: Civilização Brasileira, 2003.

COX, Robert W.; SINCLAIR, Timothy J. (Ed.). Approaches to world order. Cambridge: Cambridge University, 1996.

COX, Robert W. Production, power and world order: social forces in the making of history. New York: Columbia University, 1987.

COX, Robert W. A perspective on globalization. In: MITTELMAN, James H. (Ed.). Globalization: critical reflections. London: L. Rienner, 1997.

GILL, Stephen. Power and resistance in the new world order. Basingstoke: PalgraveMacmillan, 2003.

GILL, Stephen; LAW, David. Global hegemony and the structural power of capital. In: GILL, Stephen (Ed.). Gramsci, historical materialism and international relations. Cambridge: Cambridge University, 1994.

GILL, Stephen. (Ed.). Gramsci, historical materialism and international relations. Cambridge: Cambridge University, 1994.

GILL, Stephen. American hegemony and the trilateral commission. Cambridge: Cambridge University, 1990.

GRUPPI, Luciano. Il concetto di egemonia In: Gramsci Rome: Riuniti. Translated by Carlos N. Coutinho. Rio de Janeiro: Graal, 1978.

HAY, Colin. (What's Marxist about) Marxist state theory? In: HAY, Colin; LISTER, Michael; MARSH, David. The state: theories and issues. Basingstoke: Palgrave Macmillan, 2006.

HAY, Colin; LISTER, Michael; MARSH, David. The state: theories and issues. Basingstoke: Palgrave Macmillan, 2006.

JESSOP, Bob. State power. Cambridge: Polity, 2008.

JESSOP, Bob. The future of the capitalist state. Cambridge: Polity, 2002. 
JOSEPH, Jonathan. On the limits of Neo-Gramscian International Relations: a scientific realist account of hegemony. In: AYERS, Alison J. (Ed.). Gramsci, political economy and international relations theory: modern prices and naked emperors. Basingstoke: Palgrave Macmillan, 2009. p. 67-87.

JOSEPH, Jonathan. Hegemony: a realist analysis. London: Routledge, 2002.

MEZZAROBA, Orides (Ed.) Gramsci, estado e relações internacionais. Florianópolis: Fundação Boiteux, 2005.

MITTELMAN, James. The dynamics of globalization. In: MITTELMAN, James $\mathrm{H}$. (Ed.). Globalization: critical reflections. London: L. Rienner, 1997.

MUNCK, Ronaldo. Neoliberalism, necessitarianism and alternatives in Latin America: there is no alternative (TINA)? Third World Quarterly, London, v. 24, n. 3, p. 495-311, 2003.

PANITCH, Leo. Globalization and the state. In: PANITCH, Leo et. al. The globalization decade: a critical reader. [S.l.]: Aakar books, 2006.

PANITCH, Leo. "Rethinking the role of the state". In: MITTELMAN, James H. (Ed.). Globalization: critical reflections. London: L. Rienner, 1997.

PORTELLI, Hugues. Gramsi et le bloc historic. Translated by Angelina Peralva. Rio de Janeiro: Paz e Terra, 1977.

POULANTZAS, Nicos. Political Power and social classes. Translated by Timothy O’Hagan. London: NLB, S\&W, 1973.

POULANTZAS, Nicos. Classes in contemporary classes. London: NLB, 1975

POULANTZAS, Nicos. State, power and socialism. London: NLB, 1978.

ROBINSON, William I. Global crisis and Latin America. Bulletin of Latin American Research, Caribbean, v. 23, n. 2, p 153, 2004.

ROBINSON, William I. A theory of global capitalism: production, class, and State in a transnational world. Baltimore: Johns Hopkins University, 2004a.

ROBINSON, William I. Promoting polyarchy: globalization, US intervention and hegemony. Cambridge: Cambridge University, 1996. 
ROBINSON, William I. Social theory and globalization: the rise of a transnational State. Theory and society, New York, v. 30, n. 2, p. 157-200, 2001.

SCHWARTZMANN, Kathleen C. Globalization from a world-system perspective: a new phase in the core- a new destiny for Brazil and the semiperiphery? Journal of World-systems Research, Utah, v. 12, n. 2, p. 265-307, Dec. 2006.

SEMERARO, Giovanni. Gramsci e a sociedade civil. Rio de Janeiro: Vozes, 1999.

VAN DER PIJL, Kees. Transnational classes and international relations. London: Routledge, 1998. 